\title{
Isolation of efficient phosphate solubilizing bacteria capable of enhancing tomato plant growth
}

\author{
J. A. Sharon ${ }^{1}$, L.T. Hathwaik ${ }^{1}$, G.M. Glenn ${ }^{1}$, S. H. Imam², and C.C. Lee ${ }^{1 *}$ \\ ${ }^{1}$ United States Department of Agriculture, ARS-WRRC, 800 Buchanan Street, Albany, California 94710 , \\ USA. ${ }^{2}$ Flozyme Corporation, Inc., P.O. Box 260003, Plano, Texas 75026, USA. \\ *Corresponding author: Charles.Lee@ars.usda.gov
}

\begin{abstract}
Phosphorus is one of the three macronutrients that are essential for plant growth and development. Inorganic phosphorus (P), which can make up to $70 \%$ of the total $\mathrm{P}$ content in soils, can exist in calcium-, aluminum-, or iron-complexed forms that are unavailable for plant use. As a result, mineral phosphorus, $\mathrm{P}_{2} \mathrm{O}_{5}$, is often used as a fertilizer to supplement the nutrient for crop growth. To reduce the addition of mineral phosphorus to agricultural soils, research in naturally occurring phosphate-solubilizing microorganisms has been conducted for decades. This study found bacteria that solubilized phosphate at very high rates. The most efficient of the bacteria presented in this paper, Pantoea sp. Pot1, can solubilize tricalcium phosphate $\left(\mathrm{Ca}_{3}\left(\mathrm{PO}_{4}\right)_{2}\right)$ at a rate of $956 \mathrm{mg} \mathrm{L}^{-1}$. This bacteria produces a variety of organic acids, including acetic, gluconic, formic, and propionic acids. Greenhouse experiments demonstrated that tomato plants with soil systems inoculated with Pantoea sp. Pot1 incorporated more $\mathrm{P}$ and produced much higher biomass weights than those plants without any added bacteria.
\end{abstract}

Keywords: Biofertilizer, Pantoea, phosphate solubilization, tomato growth stimulation

\section{Introduction}

Phosphorus $(\mathrm{P})$ is a macronutrient that is essential for plant growth and development. It is a component of biological molecules, such as DNA, RNA, ATP, and phospholipids, and on a macro level, it affects root development, stalk and stem strength, crop maturity, and nitrogen fixation in legumes (Khan et al., 2009). Phosphorus in soils can exist in both organic $\left(\mathrm{P}_{\mathrm{o}}\right)$ and inorganic $\left(\mathrm{P}_{\mathrm{i}}\right)$ forms; the inorganic forms of phosphorus have been calculated to account for 35 $70 \%$ of total $\mathrm{P}$ in soil (Harrison, 1987). While some
$\mathrm{P}$ minerals, like apatites and strengites, have very slow release rates, other $\mathrm{P}$ minerals, complexed with calcium, aluminum, or iron, have faster dissolution rates that are dependent on the $\mathrm{pH}$ of the surrounding soil and on the size of the particles (Pierzynski et al., 2005). Higher soil $\mathrm{pH}$ values (basic) cause aluminum and iron-complexed $\mathrm{P}$ to become more soluble, while lower soil $\mathrm{pH}$ values (acidic) promote the solubility of calcium-complexed P (Wang and Nancollas, 2008). Since the concentration of avail- 
able $\mathrm{P}$ in soil is lower than what is found in healthy plant tissues, it is common agricultural practice to apply mineral $\mathrm{P}$ fertilizers in the form of readilyavailable monocalcium phosphate or monopotassium phosphate (Schachtman et al., 1998) However, with the efficiency of the fertilizer hovering between $10-$ $25 \%$ (Isherwood, 1996), a large majority of that $P$ also becomes immobilized in inorganic and organic forms (Khan et al., 2009). Consequently, P fertilizers have become the largest market for phosphorus worldwide. Due to the demand of agriculture on global stocks of $\mathrm{P}$, it is estimated that the world will reach its maximum rate of quality mineral $\mathrm{P}$ production by 2040 at which point production will decline while agricultural demand will continue to rise (Schroder et al., 2010). Since P supplies are not easily replenished in comparison to nitrogen, it is important to better utilize $\mathrm{P}$ reserves in the soil and reclaim chemically-bound $\mathrm{P}$ (Cordell et al., 2009).

Phosphate-solubilizing bacteria (PSB) in the plant rhizosphere play a significant role in releasing P from its insoluble complexes to a form that is more readily usable by plants. The inorganic forms of $\mathrm{P}$ can be solubilized by microorganisms that secrete low molecular weight organic acids to dissolve phosphatecomplexed minerals (Goldstein, 1995) and/or chelate cations that partner with $\mathrm{P}$ ions $\left(\mathrm{PO}_{4}^{3-}\right)$ to release $\mathrm{P}$ directly into the surrounding soil solution system (Vyas and Gulati, 2009).With the current public interest in promoting more sustainable agricultural practices, using PSB, either in conjunction with or as a replacement for expensive and environmentally damaging fertilizers, would be advantageous to the agricultural industry (Barea, 2015).

Thus far, there have been decades of research on phosphate-solubilizing microorganisms which have been transferred to industrial practices since the 1950s (Krasilinikov, 1957). Specifically, soil bacteria from genera Pseudomonas, Bacillus, Rhizobium, and Enterobacter have been thought to be the most powerful P solubilizers (Hassan and Bano, 2015; Whitelaw, 1999). The less studied Pantoea genus contains several phosphate-solubilizing bacteria such as P. agglomeran (Son et al., 2006), P.eucalypti (Castagno et al., 2011), P. ananatis (Oliveira et al., 2009) P. vagans (Rfaki et al., 2014) and Pantoea sp. LUP (Jorquera et al., 2008).

This study represents an effort to isolate bacteria with the ability to effectively solubilize phosphate for plant utilization. We isolated a bacterium, Pantoea sp. Pot1, with efficient phosphate solubilization capabilities from an organic garden. When the bacterium was used as an inoculant in greenhouse experiments with tomato plants, this strain was found to be a very effective biofertilizer.

\section{Materials and Methods}

\subsection{Soil sample collection}

The roots of tomato (Solanum lycopersicum) and potato (Solanum tuberosum) plants and the immediate surrounding soil were collected in sterile sample bags from the Karl Linn Community Garden in Berkeley, California, USA. The plant roots and soil samples were transported to the laboratory, and portions were immediately plated for rhizobacteria isolation. The remainder of each sample was preserved at $4{ }^{\circ} \mathrm{C}$ for further analysis.

\subsection{Isolation of phosphate-solubilizing bacteria from tomato and potato samples}

Approximately $2 \mathrm{~g}$ of soil was scraped from the roots of each sample and deposited into sterile tubes containing $2 \mathrm{ml}$ of sterile deionized (DI) water. Each test tube was vortexed thoroughly and a series of 10 -fold dilutions was prepared down to $10^{-9} .100 \mu 1$ 
from each dilution was plated onto both Luria-Bertani (LB) media and Pikovskaya (PVK) media agar plates (Pikovskaya, 1948). The PVK medium contained (in $\left.\mathrm{g} \mathrm{L}^{-1}\right) 10$ glucose, 0.5 yeast extract, $0.5\left(\mathrm{NH}_{4}\right)_{2} \mathrm{SO}_{4}$, $0.1 \quad \mathrm{MgSO}_{4} \cdot 7 \mathrm{H}_{2} 0,5 \mathrm{Ca}_{3}\left(\mathrm{PO}_{4}\right)_{2}, 0.2 \mathrm{KCl}, 0.002$ $\mathrm{MnSO}_{4} \cdot 2 \mathrm{H}_{2} 0,0.002 \mathrm{FeSO}_{4} .7 \mathrm{H}_{2} 0$, and 15 agar. The insoluble $\mathrm{Ca}_{3}\left(\mathrm{PO}_{4}\right)_{2}$ was washed with DI water and centrifuged to remove soluble phosphate contaminants. The supernatant was discarded, and the wet $\mathrm{Ca}_{3}\left(\mathrm{PO}_{4}\right)_{2}$ was dried by using a vacuum-flask apparatus.

The colonies that grew on the LB agar plates were used to determine the overall rhizospheric bacteria count for each plant sample. The colonies that produced clearing zones in the PVK agar plates were isolated. Individual colonies from the isolation were then respotted onto new PVK plates for better analysis of clearing zone formation. All plates were incubated at $30{ }^{\circ} \mathrm{C}$ for up to 7 days. All isolates from the potato and tomato rhizospheres were named with the prefixes "Pot" and "Tom", respectively.

A modified version of the PVK was also made to test the capability of the microorganisms to solubilize aluminum phosphate $\left(\mathrm{AlPO}_{4}\right)$ and iron phosphate $\left(\mathrm{FePO}_{4}\right)$. Each of these was made with the same PVK medium recipe except for the substitution of $\mathrm{Ca}_{3}\left(\mathrm{PO}_{4}\right)_{2}$ with either $5 \mathrm{~g} \mathrm{~L}^{-1}$ of $\mathrm{AlPO}_{4}$ or $5 \mathrm{~g} \mathrm{~L}^{-1}$ of $\mathrm{FePO}_{4} \cdot 4 \mathrm{H}_{2} \mathrm{O}$. The addition of agar was omitted for any experiments using liquid growth media.

\subsection{Quantitative determination of phosphate solubi-} lizing activity on agar medium

The clearing zones formed by the bacteria on the respotted plates were quantified on the $7^{\text {th }}$ day of incubation using the following equation:

Phosphate solubilizing index $=\frac{\text { colony diameter }+ \text { clearing zone }}{\text { colony diameter }} \times 100$

\subsection{Quantitative determination of phosphate solubili- zation in PVK liquid medium}

The isolates were grown in the PVK liquid medium to better quantify the rates of $\mathrm{P}$ solubilization. $200 \mu \mathrm{l}$ of each culture $\left(1 \times 10^{8} \mathrm{cfu} \mathrm{ml}^{-1}\right)$ were inoculated into 9.8 $\mathrm{ml}$ of PVK medium with $0.5 \% \mathrm{Ca}_{3}\left(\mathrm{PO}_{4}\right)_{2}(\mathrm{w} / \mathrm{v})$ and incubated in a shaker at $30{ }^{\circ} \mathrm{C}$. Analogous cultures were grown which contained either $0.5 \% \mathrm{AlPO}_{4}$ or $0.5 \%$ $\mathrm{FePO}_{4}$ instead of $\mathrm{Ca}_{3}\left(\mathrm{PO}_{4}\right)_{2}$. At various times, $1 \mathrm{ml}$ of each culture was collected and centrifuged at 14,000 rpm for 5 min. The solubilized $P$ in the supernatant was quantified at each time point using the phosphate colorimetric kit (Sigma-Aldrich, MO, USA). The colorimetric assay was used in conjunction with a spectrophotometer which measured the absorbance of each sample at $650 \mathrm{~nm}$.

\subsection{Quantitative determination of phosphate solubili- zation in potting sand matrix}

To determine the efficacy of $\mathrm{P}$ solubilization in sand, a $5 \mathrm{ml}$ reaction containing $9 \mathrm{~g}$ of sand (acid washed and sterilized as described in 2.8), $1 \mathrm{ml}$ of PVK containing $5 \% \mathrm{Ca}_{3}\left(\mathrm{PO}_{4}\right)_{2}$, and with or without Pantoea sp. Pot1 (final concentration of $2 \times 10^{6} \mathrm{cfu} \mathrm{ml}^{-1}$ ) was added to a $15 \mathrm{ml}$ test tube. Samples were incubated at $30{ }^{\circ} \mathrm{C}$ for $24 \mathrm{~h}$. After incubation, distilled water was added to a final volume of $10 \mathrm{ml}$, the samples were shaken at $200 \mathrm{rpm}$ for $1 \mathrm{~h}$, and centrifuged at 3,500 rpm. The supernatant was then filtered through a $0.45 \mu \mathrm{m}$ filter. $\mathrm{P}$ released was measured using the phosphate colorimetric kit (Sigma-Aldrich) as described above. 


\subsection{Determination of organic acid production}

Organic acid production and identification were determined by collecting three $1 \mathrm{ml}$ aliquots from each culture at $24 \mathrm{~h}$. The samples were centrifuged to pellet the cells, and the media was filtered through a $0.45 \mu \mathrm{m}$ PVDF filter plate (Greiner, NC, USA). The samples were then centrifuged again at 3,500 rpm for 10 min to remove any residual cell particles, and the supernatant was collected in a 96-well plate (Greiner, NC, USA). Organic acids were analyzed by HPLC (Agilent 1200 series; Agilent, CA, USA) equipped with a binary pump, an HPX-87H column (Bio-Rad, CA, USA), and an RI detector. Mobile phase was $10 \mathrm{mM} \mathrm{H}_{2} \mathrm{SO}_{4}$, flow rate was $0.5 \mathrm{~mL} \mathrm{~min}^{-1}$, column compartment was $85^{\circ} \mathrm{C}$, and the RI detector was operated at its maximum of $55{ }^{\circ} \mathrm{C}$. External calibration was used to identify and quantify the products based on organic acid standards (acetic, butyric, isobutyric, formic, propionic, lactic, malic, gluconic).

\subsection{Characterization of isolates}

All isolates were subjected to Gram stains and microscopy analysis for cell type. Isolation streaking and spread plating revealed colony morphologies (color, shape, margins, diameter, opacity, and texture). In addition, all isolates were characterized genotypically by cloning and sequencing the $16 \mathrm{~S}$ rRNA. Briefly, the genomic DNA from a pure culture of each isolate was extracted and purified for PCR amplification of the 16S rRNA sequence using Pfu Ultra II Fusion HS DNA polymerase (Agilent, CA, USA) and the $27 \mathrm{f}$ (5'-agagtttgatcmtggetcag-3') and $1525 \mathrm{r}$ (5'-aaggaggtgwtccarcc-3') primers. The amplification was conducted in a GeneAmp PCR System 2700 thermocycler (Applied Biosystems, CA, USA) using the following program: $95^{\circ} \mathrm{C}$ for $5 \mathrm{~min} ; 30$ cycles at $72^{\circ} \mathrm{C}$ for $30 \mathrm{~s}, 55^{\circ} \mathrm{C}$ for $30 \mathrm{~s}$, and $72^{\circ} \mathrm{C}$ for $90 \mathrm{~s}$; and $72{ }^{\circ} \mathrm{C}$ for
$7 \mathrm{~min}$. The amplified 16S rRNA genes were cloned (Clone Jet; Thermo Fisher, MA, USA) and sequenced (ABI 3730xl; Applied Biosystems) and subjected to BLAST analysis (Altschul et al., 1990).

\subsection{Greenhouse testing}

Clean-graded, kiln-dried Monterey sand (Cemex, CA, USA) was used as the potting medium. To further purify the sand of residual contaminants, the sand was acid-washed with $0.1 \mathrm{M}$ hydrochloric acid $(\mathrm{HCl})$. The sand was submerged in the $0.1 \mathrm{M} \mathrm{HCl}$ for $24 \mathrm{~h}$, drained, and washed with 3 submersions of DI water. The $\mathrm{pH}$ of a small portion of sand was tested after the final rinse and, when necessary, calcium carbonate $\left(\mathrm{CaCO}_{3}\right)$ was added to adjust and raise the $\mathrm{pH}$ to between 7.0-7.8. The $\mathrm{CaCO}_{3}$ did not exceed $0.2 \%$ of the total sand medium. The acid-washed, neutralized sand was then autoclave sterilized.

Tomato seeds were sown into seedling trays containing the acid-washed sand. After 7 days of growth, seedlings were transplanted to larger pots $(11 \mathrm{~cm} \mathrm{x}$ $11 \mathrm{~cm}$ ) containing $950 \mathrm{~g}$ of sand. All plant growth took place at $32 \pm 5^{\circ} \mathrm{C}$ in a greenhouse with a daylight cycle of $16 \mathrm{~h}$.

After the transplantation to larger pots, the plants were subjected to different feeding conditions. The experiment consisted of 4 conditions in triplicate for a total of 12 pots. The conditions were (1) no phosphate source, (2) Pantoea sp. Pot1, (3) $\mathrm{Ca}_{3}\left(\mathrm{PO}_{4}\right)_{2}$, and (4) $\mathrm{Ca}_{3}\left(\mathrm{PO}_{4}\right)_{2}+$ Pantoea sp. Pot1. The Pot1 strain was chosen based on its superior P solubilization characteristics. The plants were all fed a modified Steiner (MS) nutrient solution (Steiner, 1984) that contained (in $\mu 1 \mathrm{~L}^{-1}$ ) 350 of $1 \mathrm{M} \mathrm{Ca}\left(\mathrm{NO}_{3}\right)_{2} \cdot 4 \mathrm{H}_{2} \mathrm{O}, 1500$ of $1 \mathrm{M}$ $\mathrm{KNO}_{3}, 98$ of $1 \mathrm{M} \mathrm{MgSO}_{4} \cdot 7 \mathrm{H}_{2} \mathrm{O}, 500$ of the micronutrient solution, and 60 of $0.09 \mathrm{M}$ FeNa-EDTA. The micronutrient solution contained (in $\mathrm{g} \mathrm{L}^{-1}$ ) 2.86 of $\mathrm{H}_{3} \mathrm{BO}_{3}, 1.81$ of $\mathrm{MnCl}_{2} \cdot 4 \mathrm{H}_{2} \mathrm{O}, 0.22$ of $\mathrm{ZnSO}_{4} .7 \mathrm{H}_{2} \mathrm{O}$, 
$0.1 \mathrm{CuSO}_{4} \cdot 5 \mathrm{H}_{2} \mathrm{O}$, and 0.025 of $\mathrm{NaMoO}_{4}$. An MS solution minus phosphate was also prepared and denoted the "no phosphate source" solution. A separate suspension of insoluble $\mathrm{Ca}_{3}\left(\mathrm{PO}_{4}\right)_{2}$ was washed and prepared as described above to a final concentration of $770 \mu \mathrm{M}$. All the solutions were sterilized through autoclaving. For the bacterial inoculum, the Pantoea sp. Pot1 was grown to a concentration of $1 \times 10^{9} \mathrm{cfu} \mathrm{m}^{-1}$. Based on recommendations from Louisiana State University Agricultural Department (Koske et al., 2005) and Salokhe et al. (2005) the plants were watered with $100 \mathrm{ml}$ of the appropriate MS solutions from the day of transplant to day 28 (4 weeks) of growth. From day 29 (week 5) to day 56 (week 8), all the plants received $200 \mathrm{ml}$ of the appropriate solutions. Ten $\mathrm{ml}$ of $\mathrm{Ca}_{3}\left(\mathrm{PO}_{4}\right)_{2}$ suspension (as described above) were added to the appropriate pots daily. Ten $\mathrm{ml}$ of bacterial culture were added to all appropriate pots once a week.

Every pot, regardless of receiving the bacterial treatment or not, was tested for bacterial counts on the day of transplant, day 28, and day 56 to determine both the bacterial levels of Pantoea sp. Pot1 as well as to establish the level of other bacterial contamination of the sterile potting medium over the length of the experiment. $1 \mathrm{~g}$ of potting medium was carefully taken from the root zone (so as not to damage the established roots). This sample was mixed with $2 \mathrm{ml}$ of sterile DI water for dilution plating.

On day 56 after transplant, after the final potting medium samples were taken, each plant shoot and root system was washed with water to remove the potting medium. After patting the plants dry to remove the surface water from the washing, the shoots were separated from the roots. Each shoot with the corresponding root was sealed in a separate porous paper bag to allow air to travel through the bag during the drying process. All the tissues were dried in a gas-fired, circulating lab dryer at $75^{\circ} \mathrm{C}$ for $18 \mathrm{~h}$. Each shoot and root was weighed after the drying process, and these data were statistically analyzed.

$\mathrm{P}$ concentration in dried plant tissue was determined by conducting North American Proficiency Testing (NAPT) method 4.30 (A\&L Western Agricultural Laboratories, CA, USA).

\subsection{Statistical analysis}

The data was subjected to analysis of variance (ANOVA) using the SigmaStat software (Systat Software Inc., CA, USA).Statistical analysis between groups was performed using 1-way ANOVA and Holm-Sidak method for multiple comparisons using the Sigma Stat software. The analysis was based on at least two or three replications of every experiment that produced quantitative data. $\mathrm{P}<0.05$ was considered statistically significant.

\section{Results}

\subsection{Isolation of phosphate-solubilizing bacteria}

Rhizospheric soil samples from potato and tomato plants were collected at an organic community garden in an effort to analyze samples that were least affected by constant agricultural turnover and mineral fertilizer addition. To screen for phosphate-solubilizing bacteria (PSB), the samples were spread on Pikovskaya (PVK) agar plates which contained insoluble phosphate. Although bacterial counts were similar between the rhizosphere of the tomato and the potato (approximately $1 \mathrm{x}$ $10^{9} \mathrm{cfu} \mathrm{m}^{-1}$ ), the number of bacteria that created clearing zones in the PVK agar were greater in the potato sample (nine) compared to the tomato sample (two). Although an effort was made to collect samples from plants that were visibly presenting healthy characteristics, the discrepancy may be due to plant differences as well as nutrient differences in the micro-environment 
of the rhizosphere. Five unique PSB strains were collected from the potato sample (all isolates named with the prefix "Pot"), and two unique PSB strains were collected from the tomato sample (both isolates named with the prefix “Tom").

\subsection{Microbe characterization}

Seven of the isolates that created clearings on the PVK agar plates were characterized in more detail. All seven isolates were found to be Gram negative and ranged from 1-1.5 $\mu \mathrm{m}$ in diameter (Table 1). Four of the five isolates from the potato rhizosphere (Pot1, Pot2, Pot4, and Pot5) produced colonies that were small, circular, opaque, and bright yellow. The other isolate (Pot7) from the potato rhizosphere produced colonies that were slightly larger than the previous four and were opaque and white. The two isolates from the tomato rhizosphere produced circular colonies that were also opaque and white.

All the isolates were further characterized by PCR amplification, sequencing, and BLAST analysis of the
16S rRNA genes (GenBank KT726362-KT726372). Isolates from the potato sample (Pot1, Pot2, Pot4, and Pot5) showed $>99 \%$ identity to various Pantoea species. The 16S rRNA genes from a potato isolate (Pot7) and tomato isolates (Tom1 and Tom2) all had $>99 \%$ identity to various Enterobacter species. In fact, isolate Tom 1 had $100 \%$ identity match to Enterobacter cloacae strain 34977. The 16S rRNA genes of the Pot1 isolate, which presented the highest level of phosphate solubilization activity (see below), were further characterized by subcloning the PCR products into plasmids and sequencing multiple clones. Six different 16 S rRNA genes were discovered in the Pot1 isolate and all showed $>99.5 \%$ identity to $16 \mathrm{~S}$ rRNA genes from various Pantoea species, including Pantoea vagans C9-1 (GenBank NC_014562.1), a commercial strain used as a biocontrol agent (BlightBan C9-1; NuFarm Americas, NC, USA). Therefore, our isolate with the highest phosphate solubilization activity was designated Pantoea sp. Pot1.

Table 1. Biochemical properties of isolated PSB strains.

\begin{tabular}{|c|c|c|c|c|c|c|c|}
\hline PSB isolates & $\begin{array}{c}\text { Phosphate } \\
\text { Solubilizing } \\
\text { Index (Agar) }\end{array}$ & $\begin{array}{c}\text { Final pH } \\
\text { of PVK } \\
\text { Liq. Med. }\end{array}$ & Color & $\begin{array}{c}\text { Approx. } \\
\text { Cell Size } \\
(\mu \mathrm{m})\end{array}$ & Species & $\begin{array}{l}\mathrm{Ca}_{3}\left(\mathrm{PO}_{4}\right)_{2} \\
\left(\mathrm{mg} \mathrm{L}^{-1}\right)\end{array}$ & $\begin{array}{l}\mathrm{FePO}_{4} \\
\left(\mathrm{mg} \mathrm{L}^{-1}\right)\end{array}$ \\
\hline Pot1 & 150 & 4.5 & yellow & 1 & Pantoea sp. & $956 \pm 6^{\mathrm{a}}$ & $46 \pm 3^{b}$ \\
\hline Pot2 & 67 & 4.5 & yellow & 1 & Pantoeasp. & $378 \pm 34^{\mathrm{c}}$ & $34 \pm 0.9^{\mathrm{d}}$ \\
\hline Pot4 & 53 & 4.5 & yellow & 1.5 & Pantoeasp. & $379 \pm 28^{c}$ & $60 \pm 5^{\mathrm{a}}$ \\
\hline Pot5 & 120 & 4.5 & yellow & 1 & Pantoeasp. & $414 \pm 15^{\mathrm{c}}$ & $36 \pm 1^{\mathrm{d}}$ \\
\hline Pot7 & 9.1 & 5.5 & white & 1 & Enterobacter sp. & $429 \pm 37^{\mathrm{c}}$ & $33 \pm 1^{\mathrm{f}}$ \\
\hline Tom 1 & 73 & 5 & white & 1 & Enterobacter cloacae strain 34977 & $356 \pm 12^{\mathrm{c}}$ & $41 \pm 4^{\mathrm{c}}$ \\
\hline Tom2 & 78 & 5 & white & 1 & Enterobacter sp. & $328 \pm 4^{\mathrm{c}}$ & $39 \pm 2.5^{\mathrm{c}}$ \\
\hline \multicolumn{8}{|l|}{ PVK Medium } \\
\hline Only & 0 & 6.5 & $\mathrm{~N} / \mathrm{A}$ & $\mathrm{N} / \mathrm{A}$ & $\mathrm{N} / \mathrm{A}$ & 53 & 0.6 \\
\hline
\end{tabular}

Isolates from potato and tomato rhizospheres are identified as "Pot" and "Tom", respectively. All solubilization rates were measured from cultures grown for $24 \mathrm{~h}$ in liquid medium. The letters superscripted next to the values indicate statistical differences at $\mathrm{P}<0.05$. 
3.3. Phosphate solubilization on agar, liquid, and sand medium

Each of the seven isolates was re-inoculated onto a PVK agar plate. The largest clearing zone, created by Pantoea sp. Pot1, had a solubilization index of 150 (Table 1). Pantoea sp. Pot5 had a smaller index of 120. At the lowest end, Enterobacter sp. Pot7 presented a clearing zone with an index of 9.1. The tomato rhizosphere isolates had significantly smaller indexes compared to Pantoea sp. Pot1.

The quantification of clearing zone activity on an agar plate provided an imprecise measure of phosphate solubilization potential. Therefore, all 7 isolates in this study were subjected to additional quantification in the PVK liquid medium. As on the agar solubilization assay, the highest $\mathrm{P}$ solubilizing activity was found in Pantoea sp. Pot1 (956 mg L-1), while the lowest activity $\left(328 \mathrm{mg} \mathrm{L}^{-1}\right)$ was found in Enterobacter sp. Tom2 (Table 1). There was much less solubilization from the other complexed phosphate sources. There was approximately 10 -fold less phosphate released from the
$\mathrm{FePO}_{4}$ by most of the isolates (Table 1). Furthermore, no more than $0.5 \mathrm{mg} \mathrm{L}^{-1}$ of phosphate was solubilized from the $\mathrm{AlPO}_{4}$ by any isolate (data not shown).

Additionally, to test if the bacteria could solubilize $P$ in potting medium (sand matrix), Pantoea sp. Pot1 was incubated in sand and $\mathrm{Ca}_{3}\left(\mathrm{PO}_{4}\right)_{2}$. After $24 \mathrm{~h}$ incubation at $30{ }^{\circ} \mathrm{C}$, the bacteria released $111.7 \pm 7.5 \mathrm{mg} \mathrm{L}^{-1}$.

\subsection{Organic acid production}

All seven isolates were able to produce some types of organic acid in the PVK liquid culture after a $24 \mathrm{~h}$ growth period (Figure 1a). After the HPLC analysis of the culture filtrates, the presence of acetic, propionic, lactic, gluconic, malic, formic, and isobutyric acids were found. The acetic acid production was found to be the highest and malic acid was the lowest produced amongst the seven isolates. Pantoea sp. Pot1 produced both the largest amount of acetic acid as well as the most types of acids (acetic, formic, gluconic, and propionic acids) in comparison to the other isolates. (a)

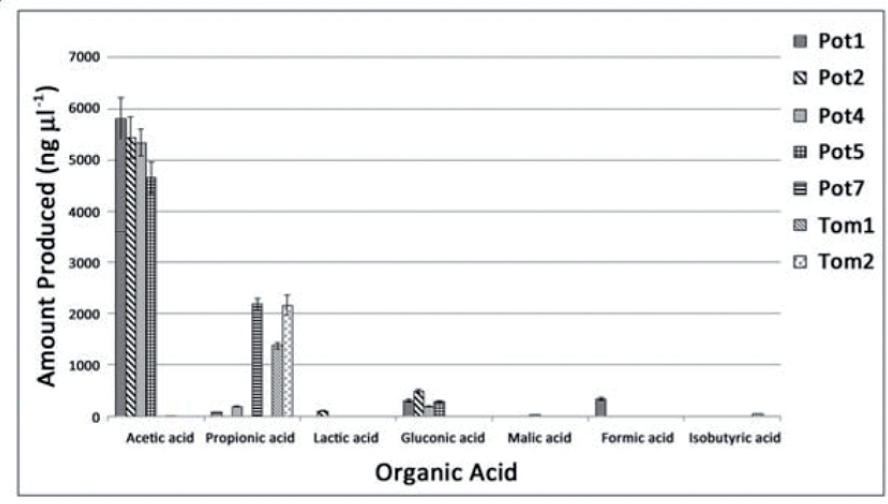

(b)

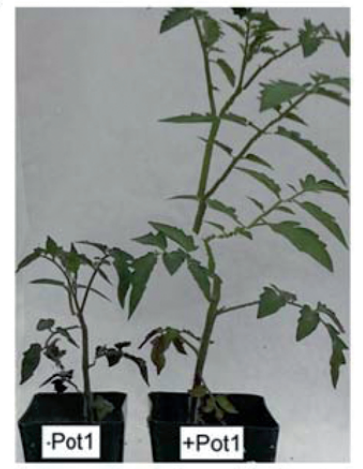

Figure 1. Bacterial acid production and effect on plant growth. (a) Production of organic acids by PSB isolates grown in PVK liquid medium after $24 \mathrm{~h}$ of incubation. Bars indicate standard error $(\mathrm{n}=3)$. (b) Greenhouse trial testing the application of Pantoea sp. Pot1 on soluble phosphorus-deprived tomato plants. Left, plant provided with only insoluble $\mathrm{Ca}_{3}\left(\mathrm{PO}_{4}\right)_{2}$. Right, plant provided with both Pantoea sp. Pot1 and insoluble $\mathrm{Ca}_{3}\left(\mathrm{PO}_{4}\right)_{2}$ 


\subsection{Efficacy of Pantoea sp. Pot1 to plant growth}

Based on its high phosphate solubilization efficiency, Pantoea sp. Pot1 was chosen for soil application for Roma tomato (Lycopersicon esculentum) plant growth in greenhouse testing. The bacterial counts of Pantoea sp. Pot1, that were added weekly at a concentration of $1 \times 10^{9} \mathrm{cfu}$ $\mathrm{ml}^{-1}$, were found to have similar amounts at the end of each week, usually varying from $6 \times 10^{8} \mathrm{cfu}$ $\mathrm{mL}^{-1}$ to $3 \times 10^{9} \mathrm{cfu} \mathrm{mL}^{-1}$. This greenhouse experiment used acid-washed sand as the growth medium. This medium was used to evaluate whether the isolate could form a rhizospheric relationship with the tomato roots while also conferring the phosphate solubilizing benefit (to the phosphorus-deprived plants) without depending on the soil system for survival.

Initial growth trials were conducted in which soil containing insoluble $\mathrm{Ca}_{3}\left(\mathrm{PO}_{4}\right)_{2}$ was supplemented with or without Pantoea sp. Pot1. The results clearly show that Pantoea sp. Pot1 was capable of enhancing plant growth in the presence of insoluble $\mathrm{Ca}_{3}\left(\mathrm{PO}_{4}\right)_{2}$ (Figure 1b). Plants supplemented with both Pantoea sp. Pot1 and $\mathrm{Ca}_{3}\left(\mathrm{PO}_{4}\right)_{2}$ (right) had much more growth than those with only $\mathrm{Ca}_{3}\left(\mathrm{PO}_{4}\right)_{2}$ (left). Thus, the cell count and growth data from the experiment show that Pantoea sp. Pot1 was not only able to survive on the tomato root exudates (carbohydrates, amino acids, etc.), but was also likely able to release the phosphate from the insoluble $\mathrm{Ca}_{3}\left(\mathrm{PO}_{4}\right)_{2}$ and make it available for use by the tomato plants.

To better quantify the degree of growth stimulation by Pantoea sp. Pot1 and $\mathrm{Ca}_{3}\left(\mathrm{PO}_{4}\right)_{2}$, we planted fresh seedlings under a variety of conditions and measured the resulting plant biomass. The dry weights of the shoots and roots of the tomato plants that were tested in the greenhouse experiments were significantly higher in the treatments that received both insoluble $\mathrm{Ca}_{3}\left(\mathrm{PO}_{4}\right)_{2}$ and Pantoea sp. Pot1, in comparison to the treatments that didn't receive any phosphate or bacteria (Figure 2). Comparing the dry shoot weights of the plants that received only the $\mathrm{Ca}_{3}\left(\mathrm{PO}_{4}\right)_{2}$ versus those that received both $\mathrm{Ca}_{3}\left(\mathrm{PO}_{4}\right)_{2}$ and Pantoea sp. Pot1, the plants inoculated with bacteria in the rhizosphere experienced 3 times increased growth. Likewise, the dry root weight showed a similar trend with 6 times greater root development from the plants with $\mathrm{Ca}_{3}\left(\mathrm{PO}_{4}\right)_{2}$ and Pantoea sp. Pot1 in comparison to those with only $\mathrm{Ca}_{3}\left(\mathrm{PO}_{4}\right)_{2}$. The phosphorus concentration in the plant tissue was significantly higher in plants supplemented with Pantoea sp. Pot1 $(0.32 \%)$ compared to those that received no bacteria $(0.17 \%)$ when $\mathrm{Ca}_{3}\left(\mathrm{PO}_{4}\right)_{2}$ was provided. 


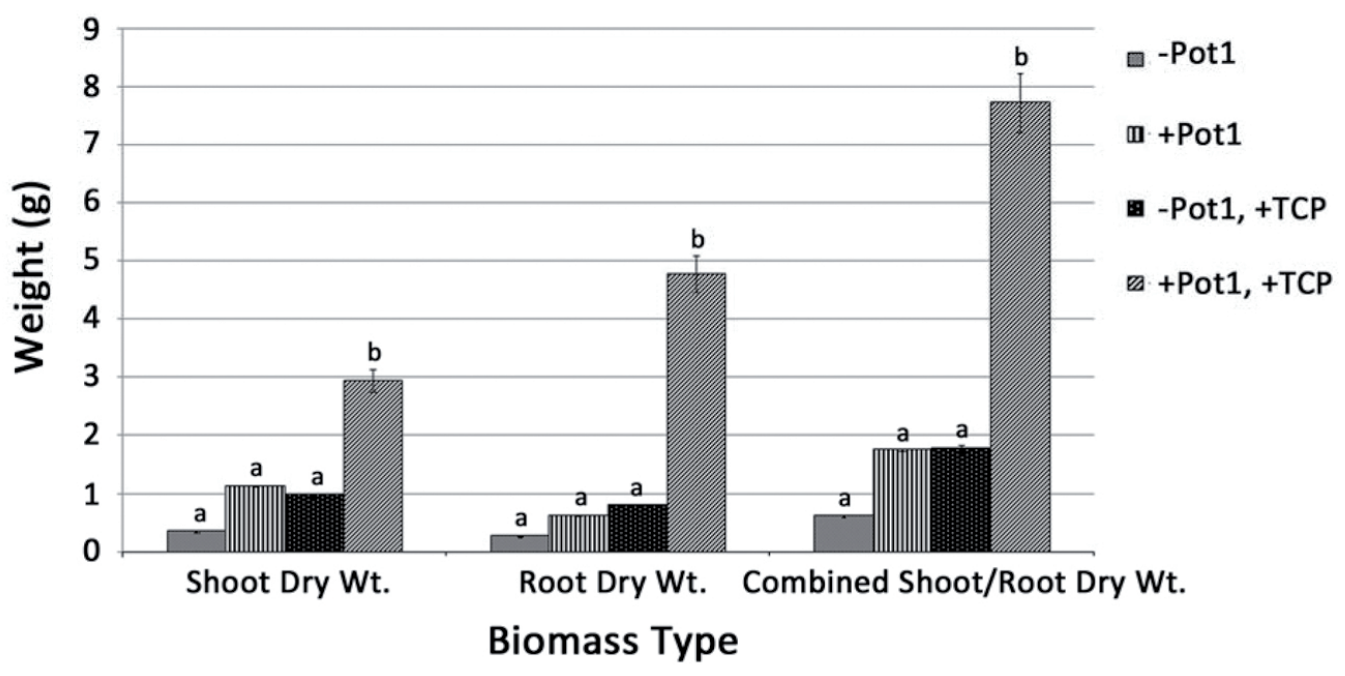

Figure 2. Dry shoot and root weights of tomato plants after 8 weeks (56 days) of growth. Each column within each group represents an exposure to different conditions. "-Pot1" indicates that no bacteria were added to those plants; "+Pot1" indicates that the Pantoea sp. Pot1 bacteria was added to those plants; "+TCP" indicates that insoluble $\mathrm{Ca}_{3}\left(\mathrm{PO}_{4}\right)_{2}$ was added to those plants. Columns with the identical letters within each set were not found significantly different at $\mathrm{P}<0.05$ when compared by pair wise multiple comparisons. Means were calculated from three replicates of each condition.

\section{Discussion}

In this study, we screened for phosphate-solubilizing bacteria from samples collected at an organic farm. We found that bacteria closely associated with potato roots solubilized significantly more $\mathrm{Ca}_{3}\left(\mathrm{PO}_{4}\right)_{2}$ than those from tomato roots. This difference could be due to the differences in the makeup of the rhizospheric microbial communities between various plant species. Smalla et al. (2001), when characterizing the rhizosphere based on host plant dependence, discovered that rhizospheric communities were similar between oilseed rape and potato plants, but both these communities varied from the community present in the strawberry rhizosphere. Likewise, Grayston et al. (1998) discovered that different plant species exude various amounts and types of carbohydrates, carboxylic acids, and amino acids, all of which can highly influence the type of microorganisms that colonize the rhizosphere. One mechanism by which phosphate can be released from the tricalcium complex is by decreasing the $\mathrm{pH}$ of the surrounding medium through the secretion of organic acids (Carrillo et al., 2002).

In general, previously identified phosphate-solubilizing microorganisms produce gluconic acid which is very effective at reducing the $\mathrm{pH}$ and, therefore, enhancing phosphate solubilization (Rodríguez and Fraga, 1999). However, this was not the case with any of these seven isolates. For the purpose of reducing the $\mathrm{pH}$ of the medium, the acids that were secreted, primarily acetic acid, were sufficient to solubilize the $\mathrm{Ca}_{3}\left(\mathrm{PO}_{4}\right)_{2}$ present.

Additionally, the low rates of solubilization when the isolates were grown in culture with either $\mathrm{AlPO}_{4}$ or 
$\mathrm{FePO}_{4}$ can be explained by this acidification mechanism of solubilization (Table 1). Aluminum $\left(\mathrm{Al}^{3+}\right)$ and iron $\left(\mathrm{Fe}^{3+}\right)$ form insoluble complexes with the phosphate ion $\left(\mathrm{PO}_{4}^{3-}\right)$ in acidic environments (Rodríguez and Fraga, 1999), thus our isolates were inefficient in solubilizing $\mathrm{FePO}_{4}$ and was unable to solubilize the phosphate complexed with aluminum.

One of our strains had the highest level of phosphate solubilization from the insoluble tricalcium complex in liquid culture ever reported to our knowledge. This strain was characterized and designated Pantoea sp. Pot1, and its rate of $\mathrm{Ca}_{3}\left(\mathrm{PO}_{4}\right)_{2}$, solubilization significantly exceeded that of other studied microorganisms, such as Pantoea agglomerans (200 $\left.\mathrm{mg} \mathrm{L}^{-1}\right)$ (Son et al., 2006), Pseudomonas fluorescens (184 $\left.\mathrm{mg} \mathrm{L}^{-1}\right)$ (Katiyar and Goel, 2003), Pseudomonas putida (247 $\mathrm{mg} \mathrm{L}^{-1}$ ) (Pandey et al., 2006), Bacillus megaterium (140 $\mathrm{mg} \mathrm{L}^{-1}$ ) (El-Komy, 2005), and Enterobacter cloacae (127 mg L-1) (Chung et al., 2005). It should be noted that such comparisons should be evaluated with the caveat that the potential variability of media and growth conditions among different laboratories may have a significant impact. When Pantoea sp. Pot1 was used to supplement tomato plants fed with insoluble phosphate, there was greatly increased plant growth which correlated with higher $\mathrm{P}$ uptake in the plant tissue. Thus, Pantoea sp. Pot1 represents a promising candidate for biofertilizer development in regions with high calcium-bound phosphate levels.

\section{Acknowledgements}

We thank the Karl Linn Community Garden in Berkeley, California, USA for access to collect plant samples. This work was supported by the United States Department of Agriculture CRIS 2030-41000-058-00 and a grant from the California Department of Food and Agriculture (\# SCB13051). The mention of firm names or trade products does not imply that they are endorsed or recommended by the US Department of
Agriculture over other firms or similar products not mentioned. USDA is an equal opportunity provider and employer.

\section{References}

Altschul, S.F., Gish, W., Miller, W., Myers, E.W., Lipman, D.J. 1990. Basic local alignment search tool. J. Mol. Biol. 215, 403-410.

Barea, J.M. 2015. Future challenges and perspectives for applying microbial biotechnology in sustainable agriculture based on a better understanding of plant-microbiome interactions. J. Soil Sci. Plant Nutr. 15, 261-282.

Carrillo, A.E., Li, C.Y., Bashan, Y. 2002. Increased acidification in the rhizosphere of cactus seedlings induced by Azospirillum brasilense. Naturwissenschaften. 89, 428-432.

Castagno, L.N., Estrella, M.J., Sannazzaro, A.I., Grassano, A.E., Ruiz, O.A. 2011. Phosphate-solubilization mechanism and in vitro plant growth promotion activity mediated by Pantoea eucalypti isolated from Lotus tenuis rhizosphere in the Salado River Basin (Argentina). J. Appl. Microbiol. 110, 1151-1165.

Chung, H., Park, M., Madhaiyan, M., Seshadri, S., Song, J., Cho, H., Sa, T. 2005. Isolation and characterization of phosphate solubilizing bacteria from the rhizosphere of crop plants of Korea. Soil Biol. Biochem. 37, 1970-1974.

Cordell, D., Drangert, J.-O., White, S. 2009. The story of phosphorus: global food security and food for thought. Global Environ. Chang. 19, 292-305.

El-Komy, H.M.A. 2005. Coimmobilization of Azospirillum lipoferum and Bacillus megaterium for successful phosphorus and nitrogen nutrition of wheat plants. Food Technol. Biotechnol. 43, 19-27. 
Goldstein, A.H. 1995. Recent progress in understanding the molecular genetics and biochemistry of calcium phosphate solubilization by gram negative bacteria. Biol. Agric. Hortic. 12, 185-193.

Grayston, S.J., Wang, S., Campbell, C.D., Edwards, A.C. 1998. Selective influence of plant species on microbial diversity in the rhizosphere. Soil Biol. Biochem. 30, 369-378.

Harrison, A.F. 1987.Soil organic phosphorus: a review of world literature. Cab International Wallingford, Wallingford, UK.

Hassan, T.U., Bano, A. 2015. The stimulatory effects of L-tryptophan and plant growth promoting rhizobacteria (PGPR) on soil health and physiology of wheat. J. Soil Sci. Plant Nutr. 15, 190-201.

Isherwood, K.F. 1996.The present situation of fertilizer production and use in the world, in: Rodriguez-Barrueco, C. (Ed.), Fertilizers and Environment. Kluwer Academic Publishers, Norwell, MA, pp. 13-18.

Jorquera, M.A., Hernández, M.T., Rengel, Z., Marschner, P., Mora, M.L. 2008. Isolation of culturable phosphobacteria with both phytatemineralization and phosphate-solubilization activity from the rhizosphere of plants grown in a volcanic soil. Biology and Fertility of Soils. 44, 1025-1034.

Katiyar, V., Goel, R. 2003. Solubilization of inorganic phosphate and plant growth promotion by cold tolerant mutants of Pseudomonas fuorescens. Microbiol. Res. 158, 163-168.

Khan, A.A., Jilani, G., Akhtar, M.S., Naqvi, S.M.S., Rasheed, M. 2009. Phosphorus solubilizing bacteria: occurrence, mechanisms and their role in crop production. J. Agric. Biol. Sci. 1, 48-58.
Koske, T.J., Hall, M., Hinson, R., Pollet, D., Sanderlin, R. 2005. Commercial growing of greenhouse tomatoes. Louisiana State University, Baton Rouge, LA.

Krasilinikov, N.A. 1957. On the role of soil microorganism in plant nutrition. Microbiologiya. 26, 659-672.

Oliveira, C.A., Alves, V.M.C., Marriel, I.E., Gomes, E.A., Scotti, M.R., Carneiro, N.P., Guimaraes, C.T., Schaffert, R.E., Sa, N.M.H. 2009. Phosphate solubilizing microorganisms isolated from rhizosphere of maize cultivated in an oxisol of the Brazilian Cerrado Biome. Soil Biol. Biochem. 41, 1782-1787.

Pandey, A., Trivedi, P., Kumar, B., Palni, L.M. 2006. Characterization of a phosphate solubilizing and antagonistic strain of Pseudomonas putida (B0) isolated from a sub-Alpine location in the Indian Central Himalaya. Curr. Microbiol. 53, 102-107.

Pierzynski, G.M., McDowell, R.W., Sims, J.T., Sharpley, A.N. 2005.Chemistry, cycling, and potential movement of inorganic phosphorus in soils, in: Sims, J.T., Sharpley, A.N. (Eds.), Phosphorus: Agriculture and the environment. American Society of Agronomy, Madison, WI, pp. 53-86.

Pikovskaya, R.I. 1948. Mobilization of phosphorus in soil in connection with the vital activity of some microbial species. Microbiology. 17, 362-370.

Rfaki, A., Nassiri, L., Ibijbijen, J. 2014. Phosphatesolubilizing bacteria in the rhizosphere of some cultivated legumes from Meknes region, Morocco. Brit. Biotechnol. J. 4, 946. 
Rodríguez, H., Fraga, R. 1999. Phosphate solubilizing bacteria and their role in plant growth promotion. Biotechnol. Adv. 17, 319-339.

Salokhe, V.M., Babel, M.S., Tantau, H.J. 2005. Water requirement of drip irrigated tomatoes grown in greenhouse in tropical environment. Agr. Water Manage. 71, 225-242.

Schachtman, D.P., Reid, R.J., Ayling, S.M. 1998. Phosphorus Uptake by Plants: From Soil to Cell. Plant Physiol. 116, 447-453.

Schroder, J.J., Cordell, D., Smit, A.L., Rosemarin, A. 2010. Sustainable use of phosphorus: EU tender ENV. B1/ETU/2009/0025, Wageningen, The Netherlands.

Smalla, K., Wieland, G., Buchner, A., Zock, A., Parzy, J., Kaiser, S., Roskot, N., Heuer, H., Berg, G. 2001. Bulk and rhizosphere soil bacterial communities studied by denaturing gradient gel electrophoresis: plant-dependent enrichment and seasonal shifts revealed. Appl. Environ. Microb. 67, 4742-4751.
Son, H.J., Park, G.T., Cha, M.S., Heo, M.S. 2006. Solubilization of insoluble inorganic phosphates by a novel salt-and $\mathrm{pH}$-tolerant Pantoea agglomerans R-42 isolated from soybean rhizosphere. Bioresource Technol. 97, 204-210.

Steiner, A.A. 1984. The universal nutrient solution, International Congress on Soilless Culture. ISOSC, The Netherlands.

Vyas, P., Gulati, A. 2009. Organic acid production in vitro and plant growth promotion in maize under controlled environment by phosphate-solubilizing fluorescent Pseudomonas. BMC Microbiol. 9, 174.

Wang, L., Nancollas, G.H. 2008. Calcium orthophosphates: crystallization and dissolution. Chem. Rev. 108, 4628-4669.

Whitelaw, M.A. 1999. Growth promotion of plants inoculated with phosphate-solubilizing fungi, in: Sparks, D.L. (Ed.), Advances in Agronomy. Academic Press, Waltham, MA, pp. 99-151. 